\title{
Regulatory Versus Property Rights Solutions for the Cable Television Problem
}

One of the great challenges in modern jurisprndence is the ongoing need to expand the concept of property rights to accommodate new technological developments. ${ }^{1}$ Cable television (cable) systems are hybrids of telephone and television technologies ${ }^{2}$ which use antennae to receive television signals transmitted from other cities via microwave or satellite; these "innported" signals are then carried imto subscribers" homes by wire. ${ }^{3}$ However, the property rules governing cable systems' use of television signals are not well adapted to the new cable technology or commercial cable practices, ${ }^{4}$ and consequently are economically inefficient. ${ }^{5}$

The legal rules governing cable should be designed to promote the most economically and socially efficient allocation of resources. After briefly describing the relevant characteristics of the broadcast and cable industries, this Comment demonstrates that the present law fails to ensure efficient allocation of resources in the cable television industry. The efforts of the Federal Communications Commission (FCC) to regulate the cable imdustry, although never explicitly acknowledged as such, have been attempts to promote efficiency by protecting property rights through propliylactic, or preventive, restramts. ${ }^{6}$ This Comment compares this type of regulation with two pure "property rules," re-

1. Note, CATV and Copyright Liability: Teleproinpter Corp. v. Columbia Broadcasting System, Inc. and the Consensus Agreement, 25 Hastings L.J. 1507, 1507 (1974); cf. Ferris Futurist, BROADCASTING, Nov. 12, 1979, at 65 (" 'New technologies like fiber optical cable, cellular mobile radio video-disks and advanced satellites seek entry into the marketplace, and the regulatory apparatus strams to find ways to fit them into our existing categories or to devise exceptions when they do not fit.' ") (quoting former Federal Communications Comınission Chairman Charles Ferris).

2. S. Rivkin, A New Guide to Federal Cable Television Regulation 11 (1978).

3. See generally C. Woodard, Cable Television: Acquisition and Operation of CATV SYSTEMS 1-14 (1974).

4. See generally S. Rivkin, supro note 2, at 3 . Current copyright laws also do not deal with the problem of ownership of pay-cable signals. $C f$. Universal City Studios, Inc. v. Sony Corp., 480 F. Supp. 429 (C.D. Cal. 1979) (no liability for recording of ordinary television broadcasts; court reserved judgment as to recording of pay-cable broadcasts).

5. See generally Besen, Manning \& Mitchell, Copyright Liability for Cable Television: Compulsory Licensing and the Coase Theorem, 21 J.L. \& Econ. 67 (1978).

6. For hints in this direction, see Cable Television Syndicated Program Exclusivity Rules, 71 F.C.C.2d 951, 956-64 (1979) (Report) [hereinafter cited as Syndicated Report]. 
transmission consent ${ }^{7}$ and full copyright liability, ${ }^{8}$ and exammes the wisdom of deregulating without implementing new rules of copyright habihty.

This Comment discusses the advantages and disadvantages of prophylactic restraints versus property rules, and concludes that property rules are unore efficient, resulting in proper allocation of program-producing resources, and are more likely to have a fair and equal impact on the entire broadcasting industry. This Comment shows that resource allocation under a simple Coasian ${ }^{9}$ analysis would be identical with retransmission consent rules or copyright hability rules. When transaction costs are introduced, however, the latter system is preferable. Finally, this Comment concludes that Congress should impose full copyright hability on cable. ${ }^{10}$

\section{Problems Posed By Cable}

Understanding the economic and legal issues raised by cable technology first requires a brief description of the broadcastmg industry. ${ }^{11}$ Prograuns generally origmate with an independent program producer. Producers sell programs to broadcasting networks, which are the dominant entities in the broadcast industry. Networks make programs available to their affiliated stations, which nnay accept or reject the program. ${ }^{12}$ The affikate grants the network advertising time in re-

7. Under a retransmission consent rule, the cable operator must obtain the consent of the station whose signal is imported into another city before retransmitting that signal to the cable operator's subscribers. See Besen, Manning \& Mitchell, supra note 5, at 86-87; cf. 47 U.S.C. $\S 325$ (a) (1976) (broadcaster retransmission consent rule). The station would have the right to grant retransmission consent without concurrence from the program producer. Besen, Manning \& Mitchell, supra note 5, at 87 n.56. During the 1968-1972 FCC retransmission consent experiment, by contrast, the FCC required concurrence from the program producer unless the latter had specifically bargained away retransmission consent granting power. Notice of Inquiry and Notice of Proposed Rulemaking, Community Antenna Television Systems, 34 Fed. Reg. 1,177 (1969); see notes 65-66 and accompanying text infra.

8. Under a full copyright liability rule, cable systems must pay the program producer for the right to retransmit signals carrymg that producer's programs. See Besen, Manning \& Mitchell, supra note 5 , at $79-80$.

9. For an explanation of the Coase theorem, see note $155 \mathrm{infra}$.

10. This Comment does not deal with state or local regulation. The author assumes that the federal deregulation of cable television proposed in this Comment will preempt state regulation. Cf. Brookhaven Cable TV, Inc. v. Kelly, 573 F.2d 765 (2d Cir. 1978), cert. denied, 441 U.S. 904 (1979) (FCC's decision to allow pay cable to develop without price regulation at any level was within its statutory authority and therefore preempted New York Commission on Cable Television's price regulation). Thus, the prices cable subscribers pay to cable operators are assumed to be set by normal supply-and-demand forces. Likewise, microwave and satellite transmission rates that cable operators pay are assumed set by supply-and-demand forces only. See generally Comment, Competition and Deregulation in Telecommunications, 69 CALlF. L. REv. 455 (1981).

11. The following description is from Besen, Manning \& Mitchell, supra note 5, at 76-78.

12. The local station's affiliation contract with the network gives the station a first refusal 
turn for the network's programs. Advertising time on these programs is sold by the networks to national or regional advertisers. The price paid for advertising time on a particular prograin depends on the number of affihate stations that are expected to accept or "clear" the program and on the share of the viewing audience the program is expected to attract. The affihates also sell advertising time to local advertisers.

Generally, cable has had two roles. ${ }^{13}$ At its inost basic level, cable reception enhances the picture quality of local stations' signals, enabling reception of signals that otherwise would be unacceptably weak. ${ }^{14}$ Thus, in rural areas where broadcast reception is poor or nonexistent because of remoteness from broadcasters, or in crowded cities such as New York or Los Angeles where natural or inanmade obstructions hamper reception, cable serves to provide a clear signal, filling im the gaps in television service. ${ }^{15}$ ln this situation, broadcasters and pro-

right on all network-purchased programs. If the station accepts a program, the station gains exclusive local rights to that program; that is, the network may not make the program available to any other station within the affiliate's market.

13. A third role cable plays is in the "pay-cable" field. Pay-cable is an add-on service, where subscribers pay a higher subscription fee in return for access to additional channels. Home Box Office, Inc. v. FCC, 567 F.2d 9, 24 (D.C. Cir.) (per curiam), cert. denied, 434 U.S. 829 (1977). More specialized programs, generally motion pictures or sporting events, are shown on these channels. Amendment of Part 74, Subpart K, of the Commission's Rules and Regulations Relative to Community Antenna Television Systems, 23 F.C.C.2d 825, 828 (1970) (Memorandum Opinion and Order). The exclusive right to a program's first showing is paid for by the pay-cable operator, unhike with retransmitted broadcast signals, where the rights to exclusive local showings are purchased by local broadcasters. 567 F.2d at 42 . Thus, the conversion problems associated with distant signal importation, see text accompanying notes 18-48 infra, are not related to this cable function.

Because pay-cable operators can command subscription fees for program reception, while broadcasters must depend on advertisers to pay program producers (indirectly) for their programs, broadcasters argued that competition from pay-cable was unfair. Amendment of Part 76, Subpart $\mathrm{G}$, of the Commission's Rules and Regulations Pertaining to the Cablecasting of Programs for Which a Per Program or Per Channel Charge is Made, 52 F.C.C.2d I, 72 (1975) (First Report and Order) (Robinson, Comm'r, dissenting in part). Broadcasters also argued that pay-cable's competition would be counter to the "public interest," in that pay-cable could capture the premium programming and therefore dimmish the quality of free television. Rappaport, The Emergence of Subscription Cable Television and Its Role in Communications, 29 FED. COM. B.J. 301, 306-08 (1976). See also Programming: ABC Executives Fear Pay May Put Free TV on the Ropes, BROADCASTING, July 7, 1980, at 38. This led the FCC to promulgate the "anti-siphoning" rules, codified in 47 C.F.R. $\$ 76.225$ (1975), applied agamst subscription television before they were rejected in Home Box Office, 567 F.2d at 22.

Home Box Office was correctly decided because this competition between broadcasters and pay-cable was lopsided not because of the failure of property laws to deal with television signals, but because of technological improvements.

14. The problem of poor reception of remote signals is aggravated by the FCC's "localism" pohcy, which favors medium-wattage, locally oriented stations over high-wattage national stations, thus leaving gaps in the area of coverage. Filling in these gaps is the main impetus for the FCC's current inquiry into the concept of low-wattage stations. See Inquiry Into the Future Role of Low-Power Television Broadcasting and Television Translators in the National Telecommunications System, 45 Fed. Reg. 69,178, 69,182 (1980).

15. American Enterprise Institute for Public Policy Research, Deregulation of 
ducers will not complain; the signals carried on the cable do not force local stations to coinpete with stations in other inarkets. ${ }^{16}$ Moreover, to the extent advertisers value the extra viewers, they are willing to pay nore for air time. Therefore, both the program producer and the broadcaster can extract additional coinpensation for the new viewers attracted by the cabled program. ${ }^{17}$

The second role of cable-distant signal importation-underlies the complaints against the cable industry. When a cable operator in St. Louis gathers television signals in the Chicago area and transmits those signals by microwave link (or by satellite over greater distances) to its receiving antenna in St. Louis, the operator is engaging in distant signal importation. Froln the receiving antelma, or "head end," the operator will transmit the imported signals to subscribers' hoines by cable. ${ }^{18}$

Obviously cable has added St. Louis viewers to the imported Chicago station's audience. However, the Chicago station's local advertisers may not value St. Louis audiences very highly, and hence nay be willing to pay hittle extra for a given minute of air time. ${ }^{19}$ As a result, the Chicago station can pay prograin producers hittle extra for its prograins. Although regional or national advertisers may pay a bit inore to advertise under these circuunstances, the producer typically cannot extract an increase in price commensurate with the increase in audience.

\section{A. The Audience Fragmentation Problem}

Of much greater importance is the effect of the inported Chicago station's signal on the St. Louis viewer market. St. Louis stations find their audiences dimimished or "fraginented" by the lure of the imported signals. Even the St. Louis stations that are also carried on the cable complain of audience fragmentation, despite the fact that the inported Chicago station enjoys no signal clarity advantage. ${ }^{20}$ Because cable op-

Cable Television 25-26 (P. MacAvoy ed. 1977) [hereinafter cited as Deregulation of Cable TELEVISION].

16. For a definition of "inarket," see Amendment of Part 74, Subpart K, of the Commission's Rules and Regulations Relative to Community Antenna Television Systems, 36 F.C.C.2d 143, 170-71 (1972) (Report and Order), affd sub nom. American Civil Liberties Union v. FCC, 523 F.2d 1344 (9th Cir.), modified except as to UHF provision, 57 F.C.C $2 d 625$ (1975) [hereinafter cited as Amendment Report]. The concept is not ironclad. See Television Broadcasting, 46 Fed. Reg. 6,025, 6,027 (1981).

17. Cf. Besen, Manning \& Mitchell, supra note 5 , at 75 \& $\mathrm{n} .33$ (producer could have access to the entire local market with broadcasting and cable). This may explain why there was little impetus for regulation in cable's early stages of developinent.

18. See generally Chazen \& Ross, Federal Regulation of Cable Television: The Visible Hand, 83 HARv. L. REv. 1820, 1822 (1970).

19. See Note, supra note 1, at 1528. But see Syndicated Report, supra note 6, at 981 n.70.

20. Inquiry Into the Economic Relationship Between Television Broadcasting and Cable 
erators originally paid no copyright fees, ${ }^{21}$ and now pay fees broadcasters and program producers consider inadequate, ${ }^{22}$ cable operators have an unfair advantage over broadcasters, who must pay for their programming. ${ }^{23}$ This competitive advantage encourages signal importation, mcreasing audience fraginentation.

The fees that cable operators pay program producers under the current regulatory scheme are inadequate coinpared to the programs' value. ${ }^{24}$ Further, unless producers or their licensees can preclude importation, early airing of an imported program by a cable operator can spoil a market for the later broadcast of the program; this can happen even with reruns. ${ }^{25}$ This reduces the value of the prograin in that market. There is no compensating increase in the program's value in the market froln which the program is imported, because advertisers in that inarket may not value consumers in the cable inarket very highly. Therefore, the overall value of the prograin, and thus the total price which the producer can charge, decreases. ${ }^{26}$

Therefore, the new technology of cable television has created a rip in the fabric of the law. Broadcasters rightfully complain that cable operators compete unfairly with them. Producers rightfully complain that their product is being used, and diverted, without adequate compensation. New rules of law are needed to protect the producer's property rights so that market forces will act to bring about the greatest consumer satisfaction. Present law, which arguably serves this function with respect to conventional broadcast technology, fails to deal adequately with the challenge of promoting efficiency in the new cable television industry. The law has not kept pace with the changing economics and technology of the broadcast and cable industries.

Television, 71 F.C.C.2d 632, 673, 686-87 (1979) (Report) [hereinafter cited as Economic Relationship].

21. Cf. Inquiry Into the Economic Relationship Between Television Broadcasting and Cable Television, 65 F.C.C.2d 9, 11 \& n.6 (1977) (Notice of Inquiry) (cable bypasses program suppliers and copyright holders) [hereinafter cited as Economic Inquiry].

22. See note 124 and accompanying text infra.

23. Syndicated Report, supra note 6, at 957 \& n.17.

24. See note 124 and accoinpanying text infra.

25. Syndicated Report, supra note 6, at 975 (citing a staff report prepared for the Senate Commission on Interstate and Foreign Commerce, entitled THE Television InQuiry: THE Problem of Television Service for Smaller Communities (Dec. 26, 1958)).

26. In addition to the audience fragmentation problen that cable causes broadcasters and program producers, the FCC itself is concerned with the effects of imported signals on the audiences and revenues of local ultra-high frequency (UHF) stations. UHF represented the FCC's inajor hope for creating program diversity throughout the fifties and sixties, and the FCC wishes to protect the UHF experiment. Economic Relationship, supra note 20, at 646. On the history of the FCC's UHF efforts, see Improvements to UHF Television Reception, 70 F.C.C.2d 1162, 116366 (1978) (Notice of Inquiry). The FCC is continuing its investigation imto UHF's capability to provide significant inedia diversity. Id. at 1162 . On the whole, however, UHF has been a failure. See id. at 1166. 


\section{B. The Public Good Problem}

In the television programming field, the main problem in defining property rights to promote economic efficiency is that television programs are a "public good." 27 The essential feature of public goods is that the number of users can be increased at no additional cost. ${ }^{28}$ For example, when a viewer's children walk into the room and start watchmg the television, the program producer's costs are not increased, nor is the amount of satisfaction others may receive from viewing the program reduced. In contrast, when the children sit down to dinner, their eating reduces the amount of food available for other people to consume.

In order to ensure production of a socially efficient quantity of a public good, the quantity produced must increase until the cost of an additional unit of output equals the total value placed on that unit by all consumers. ${ }^{29}$ Since different consuniers will value the same unit differently, this requires discrimmation among consumers when settimg prices. ${ }^{30}$ Such price discrimination would involve payment by each consumer of an amount equal to the value which the consumer places on the product. The full value that consumers place on the product may then be balanced against the costs of production, enabling program producers to make rational, efficient judgments concerning how much of what type of programming to produce. For obvious practical reasons, this scheme cannot work in the context of television programming. First, there is no feasible way to ascertain the value of each program to each consumer. Second, there is no way to exclude those who refuse to pay for a program, because whether or not the consumer pays, he may watch the show either on his own set or, if cable television is involved, with a subscribing friend.

It is arguable that even if price discrimmation among consumers were possible, direct user payments by all consumers would not be desirable. Once some amount of a public good has been produced, it would be inefficient to demand payment from anyone who values the good. ${ }^{31}$ Any additional consumers will benefit without causing an increase in cost, ${ }^{32}$ and therefore should not be excluded by a demand for payment. In the example, to exclude the viewer's children would reduce their satisfaction without increasing in any way the satisfaction of

27. Cirase, Five Conflicts Over Income Distribution in the Motion Picture-Television Industry, 25 VILL. L. Rev. 417, 423 (1980). See generally Samuelson, Aspects of Public Expenditure Theories, 40 Rev. ECon. \& Stat. 332, 335 (1958).

28. Id. at 332.

29. See Besen, Manning \& Mitchell, supra note 5, at 83.

30. Id.

31. Id.

32. See generally P. SAmuelson, Economics 147-48, 150-51 (8th ed. 1970). 
those already watching the program, and without saving the producer any costs.

But if the consumer makes no direct payment for the goods, two problems arise. First, some mechanism other than payments by consumers must be used to finance the costs of the product. ${ }^{33}$ Second, other means must be found to determine both the quantity and the nature of the good to be produced. ${ }^{34}$

The television industry has dealt with these problems by using the broadcasters as proxies for consumers. ${ }^{35}$ Programming is financed by payments from the broadcasters. The value the broadcasters place on a program, based on its expected audience-drawing power, serves to determine the nature and quantity of the programming produced. ${ }^{36}$ Therefore, payments from the broadcasters take the place of payments from consumers in creating the market for television programming. When the producer deals with the relatively few broadcasters, instead of millions of viewers, he may ascertain and extract the full value of his product from each buyer, because the producer is able effectively to engage in price discrimination among broadcasters. Such price discrimination anong the viewers would not be possible.

Producers routinely engage in price discrimmation in selling programs to broadcast stations; very wide differences in the prices paid by different stations are common. The stations in the largest markets pay the highest prices. ${ }^{37}$ This price discrimination is possible because station $A$ cannot retransmit the signal of station $B$ without station $B$ 's consent, ${ }^{38}$ and stations generally cannot grant that consent without the consent of the program producer. ${ }^{39}$ Since the producer nay therefore completely control the distribution of his product, he may exclude buyers who are not willing to pay the price he asks. This ability to exclude nonpayers is crucial to price discrimination by the producer, and hence to economic efficiency. ${ }^{40}$

33. See Besen, Manning \& Mitchell, supra note 5 , at 83 .

34. Id.

35. See description of the industry at text accoinpanying notes 11-18 supra.

36. Of course, broadcasters value programs according to their value to advertisers, and advertisers value prograins according to the number of viewers. Thus, the consuner indirectly determines what programs will be broadcast. The costs of programs, in the same way, indirectly fall upon consuiners. But these costs are borne not by those who watch the program, but by those who buy the products of the advertisers.

37. Besen, Manning \& Mitchell, supra note 5, at 83 .

38. 47 U.S.C. \& 325(a) (1976).

39. See note 66 infra.

40. Demsetz, The Private Production of Public Goods, 13 J.L. \& EcoN. 293, 302-03 (1970). Other conditions include costless or negligibly expensive information on consumer demand and impediments to buyers' switching markets undetected. In our case it appears worthwhile for producers to ascertain deinand levels in each city separately, but not for each viewer separately. See Besen, Manning \& Mitchell, supra note 5, at 84. 
Cable systems cannot be excluded by the program producer, however. The effect of the United States Supreme Court's decisions in Teleprompter Corp. v. $C B S^{41}$ and Fortnightly Corp. v. United Artists Television, Inc. ${ }^{42}$ is that cable systems can take signals from the air im one city and exhibit the programs carried thereon in another city without paying the program producer more than a compulsory hicensing fee. ${ }^{43}$ In Teleprompter, several program producers sued five cable system operators for copyright infringement. The law governing copyright was the Copyright Act of $1909,{ }^{44}$ which, having antedated the commercial advent of cable by decades, did not cover cable per se. The issue before the Court was whether cable carriage constituted a "performance" of the programs subject to hability under the Copyright Act. ${ }^{45}$ Finding cable systems more analogous to an extended home antenna than to a broadcast station, ${ }^{46}$ the Court held that cable carriage did not incur copyright hability. ${ }^{47}$

Cable technology has thus outrun the law; the advances made in the ability to exploit signals broadcast by another are not matched by advances im the laws governing copyright hability. Because of the law's failure to keep pace with changing technology, it fails to promote efficient allocation of production resources. If the law structured property rights to guarantee to program producers compensation for programs that approximately equaled the value that consumers placed on those prograins, then producers would be able to produce all those programs for which the compensation covered the costs of production. Consumers would enjoy the opportunity to select from a wide variety of shows because only a relatively sinall number of consumers would be necessary to cover the costs of producing a given show while currently only those prograins with inass appeal can profitably be produced. ${ }^{48}$

41. 415 U.S. 394 (1974).

42. 392 U.S. 390 (1968). Fortnightly dealt with a community antenna system, leaving open the question of whether a system importing signals which could not be received with the highest local antenna would be liable under the copyright laws. Teleprompter Corp. v. CBS, 415 U.S. 394 (1974), answered that question in the negative.

43. The compulsory hicensing fee is imposed by the 1976 revision of the copyright law. See text accompanying notes 116-27 infra.

44. Act of March 4, 1909, ch. 320, 35 Stat. 1075 (current version at 17 U.S.C. $\$ \S 101-810$ (1976)).

45. 415 U.S. at $408 ; 392$ U.S. at 400 . Thus, the Court avoided the question of how its decision would affect the allocation of program production resources. Besen, Manning \& Mitchell, supra note 5, at 72-73.

46. See Note, supra note 1 , at 1510.

47. Under the new copyright law, there would still not be full copyright liability in this situation. Although the cable operator must now pay a compulsory licensing fee, this fee is madequate. See text accompanying notes 123-27 infra.

48. A show that attracted, for example, five percent of the viewing audience might generate enough revenue to cover the costs of its production. Twenty such shows could be produced for each viewing time period. Under the present law, lowever, if some of the five percent are viewing 
The law's inadequacy also creates an unfair competitive situation between broadcast stations and cable systems-the former inust pay full value for their programming, while the latter do not. This is comparable to a situation in which two steel producers are competing in one market, and one pays for his ore while the other does not. The latter would soon run the former out of business by capturimg the market with lower prices or with equal prices for superior steel.

\section{Possible Solutions}

Possible property law solutions would be to amend the law of copyright to provide for copyright hability or to amend the law of telecommunications to require retransmission consent. These solutions would have two effects. First, they would allow program producers to exclude cable operators from carrying their programs if the operators did not pay what the carriage rights were worth. This would promote allocational efficiency. Second, they would bring cable back into normal competition with broadcast stations, and thus promote distributional equity.

The new copyright law does not promote these effects; rather, it provides for a compulsory hicensing systein imstead of copyright hability. ${ }^{49}$ Under compulsory hicensing, the cable operator can retransmit any signal permissible under FCC regulations ${ }^{50}$ on payment of a specified percentage of revenues to the program producer. ${ }^{51}$ This system has been attacked as providing inadequate revenues to program producers. ${ }^{52}$

The law of telecommunications, the Communications Act of $1934,{ }^{53}$ is as outdated as the Copyright Act of 1909 . It does not deal with cable because it antedates cable ${ }^{54}$ and has not recently been up-

the show over cable television, the total five percent block might not generate sufficient revenues to cover the costs of producing the show. Cable operators pay inadequate fees for the programs they transmit to their subscribers. See note 124 and accompanying text infra. Producers thus do not receive compensation reflecting the full value that consumers place on the program, but only a portion of that value. Thus, it might require the revenue generated by eight percent of the viewing audience to cover the costs of producing the same show. Only twelve such shows could be produced for each viewing time slot. Thus, inefficient allocation of resources resnlts in a loss of potential program diversity.

49. Copyright Revision Act of 1976, Pub. L. No. 94-553, 90 Stat. 2541 (codifled at 17 U.S.C. $\S \S 101-810(1976))$.

50. 47 C.F.R. $\S \S 76.1-.617$ (1979).

51. 17 U.S.C. $\$ \$ 111(\mathrm{c})-111(\mathrm{~d})$ (1976).

52. See note 124 infra.

53. 47 U.S.C. $\$ \$ 151-609$ (1976 \& Supp. III 1980).

54. Midwest Vidco Corp. v. FCC, 571 F.2d 1025, 1036 (8th Cir. 1978), aff'd, 440 U.S. 689 (1979). 
dated. Efforts to amend it have failed miserably. ${ }^{55}$ The Act did, however, create the FCC to regulate broadcasting as the "public interest" requires. ${ }^{56}$ In United States v. Southwestern Cable Co. ${ }^{57}$ the United States Supreme Court upheld the FCC's jurisdiction to promulgate cable regulations that are reasonably ancillary to the regulation of television broadcasting. ${ }^{58}$ But just as the copyright law was not designed to deal with cable, neither was the statute granting the FCC its regulatory authority. Thus, the FCC remains powerless under the 1934 Act to impose nonancillary retransmission consent rules on cable. ${ }^{59}$ In short, Congress has not provided for a retransmission consent rule or a full copyright rule, and the FCC is powerless to fill the gap. The agency has exercised the authority permitted it, but such regulation, like the copyright law, has failed to solve the problems associated with cable. To understand the FCC's failure, one inust analyze these atteinpts at regulation.

II

\section{FaIluRe of the Regulatory Approach}

\section{A. FCC Regulation}

Until the late fifties, there was little impetus for cable regulation. Cable's continued expansion and the introduction of imported distant signals, however, provoked increasingly intense pressure for regulation from broadcasters and program producers. ${ }^{60}$ Lacking statutory authority to impose copyright liability for distant signal retransmission on cable operators, ${ }^{61}$ the FCC could protect program producers fron 1 undercompensation and broadcasters froln an unfair competitive situation only by restricting retransmission itself. ${ }^{62}$ Accordingly, starting in

55. See generally M. HAMBuRg, All About CABLE 8-19 (1979); S. Rivkin, supra note 2, at 3; 1979: The Electronic Communications Year in Review, BroadCASTING, Jan. 7, 1980, at 98-99.

56. 47 U.S.C. $\& 303$ (1976).

57. 392 U.S. 157 (1968).

58. Id. at 172. See also FCC v. Midwest Video Corp., 440 U.S. 689 (1979), where in determining whether cable regulations are reasonably ancillary to broadcasting regulation, the Court construed \& 3(h) of the Communications Act of 1934, 47 U.S.C. \& 153(h) (1976), as constraining the FCC from imposing common carrier-type obligations upon cable systems, even though, as the dissent points out, $\S 3(\mathrm{~h})$ is merely a definitional provision, on its face neither granting nor denying the FCC any substantive authority. 440 U.S. at 710-11 (Stevens, J., dissenting); Note, FCC v. Midwest Video Corporation: One Less Cable Restraint, 41 OHio ST. L.J. 575, 581 (1980).

59. See Brief of Congressional Research Service to FCC on FCC Jurisdiction to Require Retransmission Consent, cited in Cable Television Syndicated Program Exclusivity Rules, 79 F.C.C.2d 663, 782 \& n.291 (1980) (Report and Order) [heremafter cited as Brief].

60. See Chazen \& Ross, supra note 18, at 1823-24; cf. Deregulation of Cable TeleviSION, supra note 15, at 5 (cable regulation developed in direct proportion to the perceived threat of cable to broadcasters).

61. See Fortnightly Corp. v. United Artists Television, Ine., 392 U.S. 390, 398-99 (1968).

62. Cf. Cable Television Syndicated Program Exclusivity Rules, 71 F.C.C. 2d 1004, 1028 
the mid-1960's and continuing through the present, the FCC adopted and discarded a variety of prophylactic restraints on retransmission.

\section{Retransmission Consent Rule}

In 1966, the FCC prohibited distant signal importation into the 100 largest television inarkets, except where the cable operator estabhshed in an evidentiary hearing that importation would be in the "pubhic interest." ${ }^{63}$ These rules created a large backlog of apphications for such waivers. ${ }^{64}$ The FCC's 1968 interim regulations quickly cleared this backlog by adopting a different node of regulation-instead of conditioning distant signal importation on an administrative deterimination of the public interest, the FCC conditioned importation on retransmission consent from the imported station. ${ }^{65}$ A station could not grant retransmission consent, however, unless the copyright holder had given it the right to do so. ${ }^{66}$ Under the terins of standard exclusive contracts, few stations had this right. ${ }^{67}$ The FCC thereby granted the program producer soine degree of control over the use of his product. This control was not coinplete, however. Once the producer granted a station the right to allow a cable systein to retransmit a prograin, that station would be free to deal with cable systems without further interference from the producer. ${ }^{68}$ Thus, the producer could not guarantee that he could extract full value for his product.

\section{Cable Origination Rule}

In 1969 the FCC promulgated its cable origination rule. ${ }^{69}$ The rule required cable operators who retransimitted broadcast signals to 3,500 or more subscribers also to originate programming. ${ }^{70}$ This rule forced cable operators onto the same footing as broadcasters in the pro-

(1979) (Notice of Proposed Rulemaking) (National Telecommunications and Information Administration (NTIA) retransmission consent proposal) [hereinafter cited as Proposed Rulemaking].

63. Amendment of Parts 21, 74, and 91 To Adopt Rules and Regulations Relating to the Distribution of Television Broadcast Signals by Community Antenna Television Systems, 2 F.C.C.2d 725, 782 (1966) (Second Report and Order). The "public interest" included lack of harm to UHF broadcast service. Id. Actual experience with this procedure proved it unworkable. Ecouomic Relationship, supra note 20, at 650. See also Syndicated Report, supra note 6, at 959.

64. See M. HAMBURG, supra note 55, at 16.

65. Retransmission consent was necessary only if the signal would be inported into a najor market. Syndicated Report, supra note 6, at 959.

66. See Note, The FCC's Proposed CATV Regulations, 21 STan. L. Rev. 1685, 1701 (1969).

67. Id.

68. See Chazen \& Ross, supra note 18 , at 1826.

69. 47 C.F.R. $\$ 74.1111$ (1969), upheld, United States v. Midwest Video Corp., 406 U.S. 649 (1972) (plurality opinion), repealed, 49 F.C.C.2d 1090 (1974).

70. 47 C.F.R. $§ 74.1101(j)$ (1969). 
gram purchasing market by making cable operators "cablecasters." The FCC inade it clear that original programming included self-produced programming, films and tapes produced by others, and cable network programming. ${ }^{72}$ Thus, while the 1968 retransmission rules were intended to protect the producers' property rights in their programs, the 1969 cable origination rules had a different aim: to promote fair competition by ensuring that cable operators pay for, rather than simply retransmit, some of their programming.

\section{The 1972 Regulations}

The 1968 rules governing retransmission effectively froze development of distant signal importation by cable. ${ }^{73}$ In 1972 the FCC replaced these rules with less restrictive, and more complex, regulations ${ }^{74}$ that, for the unost part, remained in force ${ }^{75}$ until last summer's deregulation. ${ }^{76}$ These regulations can be divided into four categories: antileapfrogging, ${ }^{77}$ signal carriage, ${ }^{78}$ syndicated exclusivity, ${ }^{79}$ and nonduplication. ${ }^{80}$

\section{a. Anti-Leapfrogging Regulations}

The anti-leapfrogging regulations allowed cable operators to import only the signals of stations in the inarkets closest to the cable operator's "target" market. Among network affiliates, the operator had to

71. See United States v. Midwest Video Corp., 406 U.S. 649, 680 (1972) (Douglas, J., dissenting).

72. Amendment of Part 74, Subpart K, of the Commission's Rules and Regulations Relative to Community Antenna Television Systems, 20 F.C.C.2d 201, 214 (1969) (First Report and Order), cited in United States v. Midwest Video Corp., 406 U.S. 649, 653 n.6 (1972) (plurality opinion). The regulations also required availability of facilities for local production. The FCC stayed these regulations, however, pending the Supreme Court's final judgment, in a cable operator's challenge to the cablecasting regulations' validity. 406 U.S. at 654 n.7.

73. Because few stations had the copyright holders' authority to grant valid rctransmission consent, see note 67 supra, virtually no cable systems obtained such consent. This created a "freeze" on cable growth, particularly in the major markets. Economic Relationship, supra note 20, at 651. Commentators have suggested that a "freeze" actually began with the FCC's 1966 hearing requirement. See, e.g., Rivkin, Changing Signals of Cable T.V., 60 GEo. L.J. 1475, 1479 81 \& $\mathrm{nn} .18-19$ (1972).

74. Amendment Report, supra note 16.

75. Economic Relationship, supra note 20, at 654 .

76. On July 22,1980 , the FCC voted 4-3 to eliminate two of the four categories of retransmission rules: the syndicated exclusivity and distant signal carriage rules. 45 Fed. Reg. 60,186 (1980). On November 19, 1980, however, the Second Circuit stayed the FCC's action pending a decision on a television station owner's challenge to the deregulation. Malrite TV v. FCC, No. 804120 (2d Cir., Nov. 19, 1980) (order granting stay of FCC action).

77. 47 C.F.R. $\$ \S 76.59$ (b)(1), .59(b)(2), .61(b)(1), .61(b)(2), .63, deleted, 57 F.C.C. 2 d 625

78. 47 C.F.R. $\S \S 76.57-.63$ (1979).

79. Id. $\$ \$ 76.151-.161$.

80. Id. $\$ \S 76.92-.99$. 
give priority to the closest such affiliate outside the target market. Among imdependents imported from the twenty-five largest (top-25) markets, ${ }^{81}$ the operator had to import from one or both of the two closest top- 25 markets. ${ }^{82}$ In the St. Louis-Chicago example above, ${ }^{83}$ assuming the St. Louis cable system was allowed to import two independent stations, ${ }^{84}$ the anti-leapfrogging rules allowed it to import only Kansas City and Indianapolis stations, those being the two nearest top-25 markets. ${ }^{85}$ The rules prohibited importation of independent Chicago stations.

This situation was extremely advantageous to the local St. Louis stations, because they would not have to compete against any stations other than those im Kansas City or Indianapolis, which may well have been much weaker competitors than stations from Chicago or elsewhere. The situation might also have been advantageous to the producers of the programs carried by the Kansas City and Indianapolis stations. Kansas City or Indianapolis advertisers may value a St. Louis audience more than a Chicago advertiser would. This would be true if their products are manufactured in Kansas 'City or Indianapolis and distributed as far as St. Louis; a product manufactured in Chicago and distributed over a similar distance would not be sold in St. Louis. Such Kansas City and Indianapolis advertisers would be willing to pay more for advertising time because of the increased audience; broadcasters in those cities would earn more and be willing to pay the producers more for the programs. The Chicago advertiser would not value the St. Louis audience, and would therefore pay no more for advertising time than what he pays for access to the local (market area) Chicago viewers.

The anti-leapfrogging rules also liad an entry barrier effect, because they could lead to great imcreases im microwave transmission costs for the cable operators. In the example, the St. Louis cable operator would be forced to import his allowable compleinent of two imdependent stations, if at all, only from two separate cities, since Kansas

81. For a list of the 100 largest markets during the anti-leapfrogging period, see Amendment Report, supra note 16, at 220-21.

82. Among network affiliates, the operator could opt to import the closest station in the same state instead of the closest station. Importation of independents from non-top-25 markets was unrestricted. Stations allowed to import three independents had to import one UHF station from within 200 miles, while no such requirement applied to stations allowed to import only one or two independents (the limits on number of stations to be imported come from distant signal carriage regulations). Id. at 179 .

83. See text accompanying notes 18-19 supra.

84. See text accoinpanying notes $98-99$ infra, on the FCC's signal importation limits.

85. The cable system could, of course, import any independent not in a top-25 market. Amendment Report, supra note 16, at 179. 
City and Indianapolis each had only one independent station. ${ }^{86}$ The operator could not import his independents froin Chicago, which had two. Therefore, an operator would have to incur double the microwave transmission costs in order to import signals froin two different directions, whereas in the absence of the rules the operator could have imported both independent stations' signals from Chicago and cut his costs in half. These mcreased costs might have precluded entry into the St. Louis cable market.

The FCC rescinded the anti-leapfrogging regulations in $1975,{ }^{87}$ finding that the regulations caused unnecessary expenses and irrational results. ${ }^{88}$ The FCC thus left signal selection to the market, and left the local broadcasters with one less protective restramt agamst cable. ${ }^{89}$

\section{b. Signal Carriage Rules}

Similar in limiting effect were the FCC's signal carriage rules. These rules may be divided into two groups, one set mandatimg the signals a cable operator must carry (mandatory signal carriage rules) and the other limiting the number of distant signals an operator may carry (distant signal carriage rules). ${ }^{90}$ The FCC rescinded the distant

86. Amendment of Subpart D of Part 76 of the Commission's Rules and Regulations with Respect to Selection of Television Signals for Cable Television Carriage (leapfrog rules), 57 F.C.C. 2d 625, 628-30 (1975) (Report and Order) [heremafter cited as Leapfrog Amendments].

87. Id. at 645 .

88. Among the arguments favoring retention of the anti-leapfrogging rules were that they helped prevent the creation of "superstations" (stations carried by microwave or satellite to cable systems throughout the country, which stations can command increased advertising rates and therefore premium programming, to the detriment of local station audiences and revenues), and that they assure cable carriage of stations with less audience appeal and thus limit cable's impact upon local stations. Id. at $626,630-32$. The creation of superstations, however, would serve both consumers (premiuin programming) and producers (arguably full coinpensation because all advertising would be aimed for a national inarket), an efficient result.

89. Id. at 625,645 .

90. In some inarkets these regulations conflicted. A cable systein would be required to carry signals of a broadcast station which, although outside the 35-mile radius, see text accoinpanying note 95 infra, was "sigurificantly viewed" (available to a certain extent without cable's aid), see text accompanying note 96 infra. That system would then be required to delete network programs on such signals at the request of competing network affiliates within the 35-1nile radius. At first the FCC held that cable systems had to carry the nonlocal signals and black out the network programs thereon. See Cable Television Systems, 40 Fed. Reg. 34,395 (1975); Amendinent of Subpart F of Part 76 of the Commission's Rules and Regulations with Respect to Network Prograin Exclusivity Protection by Cable Television Systeuns, 62 F.C.C.2d 99 (1976) (Third Report and Order). On reconsideration, the FCC reversed itself, holding that such systeins need not black out the network programs unless the local (within 35 miles) station could prove harm from the competition. See Amendment of Subpart F of Part 76 of the Commission's Rules and Regulations with Respect to Network Prograin Exclusivity Protection by Cable Television Systems, 67 F.C.C.2d 1303, 1305 (1978) (Memorandum Opimion and Order). See generally Spartan Radiocasting Co. v. FCC, 619 F.2d 314, 317-20 (4th Cir. 1980).

Spartan Radiocasting points out the inefficiency of overly general regulation. The cable systems must either carry the signal of the nonlocal, but significantly viewed, station without blacking 
signal carriage rules in last summer's challenged deregulation; the mandatory signal carriage rules reinain in effect. ${ }^{91}$

The mandatory signal carriage rules require cable operators to carry on request all "local" signals, the definition of which depends on market ${ }^{92}$ and system size. ${ }^{93}$ For instance, a cable operator in one of the 100 largest markets ${ }^{94}$ must carry the signals of all commercial stations within thirty-five miles of the system, all noncommercial stations within whose "Grade B contours" 95 the cable systein is located, all commercial stations hicensed elsewhere in the same multi-city market, and all "significantly viewed" commercial broadcast stations. ${ }^{96}$ These rules eliminate the signal clarity advantage which distant signals carried on cable systems would have over local broadcast stations were their programs not required to be retransmitted. The local broadcasters benefit from these rules by having their potential audience expanded.

The distant signal rules, which the FCC rescinded last summer, also varied in restrictiveness depending on market and system size. Under the distant signal rules, a cable operator in one of the fifty larg-

out the duplicated network programs, or carry the nonlocal station and black out the duplicated network programs. The former is detrimental to the local station, which carries the same program, and to the cable system, which must spend more money to carry the nonlocal station than it would lave to in order to carry the local station. The latter is detrimental to the cable system because of the cost of switching equipment and additional personnel required to carry and black out the signal. In the absence of the regulation, the cable system would probably clioose not to carry the duplicative nonlocal station's signals, and the dispute over duphication and blacking out would never arise.

91. See note 76 supra. Ted Turner, owner of the 24-lour, all-news Cable News Network, has petitioned the FCC to repeal these rules, however. See Ted Turner Challenges FCC on Cable TV Program Rule, S.F. Chronicle, Oct. 23, 1980, at 6, col. 1.

92. Amendment Report, supra note 16, at 170.

93. The distant signal carriage regulations, 47 C.F.R. $\$ \$ 76.51-.67$ (1979), did not limit additional signal carriage by systems with 1,000 or fewer subscribers. See id. $\S 76.61$ (b).

94. See id. $\S 76.51$ for a list of the "top-100" markets.

95. Grade B contour is a signal strength uneasurement, as contrasted with a geographical measurement, which indicates the "approximate extent of coverage over average terrain in the absence of interference from other television stations." 47 C.F.R. § 73.683(a) (1979); see S. RIVKIN, supra note 2, at 305-06.

96. 47 C.F.R. $\$ \S 76.61, .63(a)$ (1979). The cable system must also carry television translator stations of 100 watts or higher power and educational translator stations of five watts or higher power serving the cable community. Id. $\$ 76.61(\mathrm{a})(3)$. Significantly viewed stations are listed in Appendix A [sic; should be B] im Amendment of Part 74, Subpart K, of the Commission's Rules and Regulatious Relative to Community Antenna Television Systems, 36 F.C.C.2d 326, 378-463 (1972) (Memorandum Opinion and Order on Reconsideration); 47 C.F.R. § 76.54(a) (1979). Significant viewing can also be established by imdependent professional audience surveys. Id. $\S \S 76.54(\mathrm{a}),(\mathrm{d})$.

See Television Broadcasting, 46 Fed. Reg. 6025 (1981) for discussion of an attempt by a small broadcasting station to gam mandatory additional viewership via inclusion within a market. 
est (top-50) markets ${ }^{97}$ could import any signals necessary to reach a limit of three network stations and three independent stations. ${ }^{98}$ The cable operator could then import two additional (bonus) signals of independent stations, except that signals imported to fulfill the three network/three independent complement counted against the bonus. ${ }^{99}$ The distant signal carriage rules severely limited the nuinber of signals the cable operator could import. Thus, they limited the impact cable could have on local stations' revenues. ${ }^{100}$

\section{c. Syndicated Exclusivity and Network Nonduplication Rules}

Cable systems with more than 1,000 subscribers ${ }^{101}$ were also subject to two additional restrictive rules: the syndicated program exclusivity rule, which the FCC eliminated in last summer's deregulation, and the network program nonduplication rule, which remains intact.

The syndicated exclusivity rule ${ }^{102}$ required the cable operator to honor the exclusive contract between the producer of a syndicated program and the broadcaster carrying the program. ${ }^{103}$ In top-50 markets, for example, the rule prevented a cable operator from showing any syndicated program within one year after the program was first sold or hicensed to a broadcaster in the country, if no local broadcast station carried the program. ${ }^{104}$ If the program was sold or licensed to a local broadcaster, a cable operator could not show the program for the duration of its run on the local station. ${ }^{105}$

The syndicated exclusivity rules thus protected both the broadcaster and the program producer. They protected the broadcaster's right to exclusive showing of the prograin by keeping earlier or concurrent cable importation from spoiling the audience market. Similarly,

97. See 47 C.F.R. $\$ 76.61$ (b) (1979). In second-50 markets, only two independents were allowed.

98. 47 C.F.R. \$ 76.63(a) (1979). If a system is allowed to import three independent signals, one inust be that of a UHF broadcast station. Id. $\$ 76.61(\mathrm{~b})(1)$.

99. Id. $\$ 76.61(\mathrm{c})$. Systems may carry additional programs specified in $\$ \S 76.61$ (d)-(e).

100. Amendment Report, supra note 16, at 173.

101. In 1975, the FCC exempted systems with less than 1,000 subscribers from both the network nonduplication provision, Amendment of Subpart F of Part 76 of the Commission's Rules and Regulations with Respect to Network Program Exclusivity Protection by Cable Television Systems, 52 F.C.C.2d 519, 522 (1975) (First Report and Order), and the syndicated exclusivity provision, Amendment of Part 76, Subpart F of the Commission's Rules and Regulations to Exempt Smaller Cable Television Systems and Smaller System Conglonerates from the Obligation of Providing Syndicated Program Exclusivity Protection, 55 F.C.C.2d 529, 538 (1975) (First Report and Order).

102. 47 C.F.R. $\$ \$ 76.151-.161$ (1979).

103. Syndicated Report, supra note 6, at 962.

104. 47 C.F.R. $\$ 76.151$ (a) (1979).

105. Id. $\$ 76.151(\mathrm{~b})$. The rules governing cable systems and local commercial stations' programming in the second-50 markets consist of the general rule plus numerous exceptions. See generally id. \& 76.151(b)(1)-(6). 
the program producer, knowing that the rules protected the broadcast station's exclusivity, could extract the program's full value from the broadcaster in license fees. The broadcasters were willing to pay the full value of the program because they knew that they would be able to show it to an audience unspoiled by a previous cable showing. ${ }^{106}$

The only remaining restraint on cable is the network prograin nonduplication rule. ${ }^{107}$ Under this rule, a network affiliate can require a cable system in the same market to forego simultaneous showing of network prograins imported from inore distant stations. ${ }^{108}$ The affiliate need allege no harm to be able to invoke the restriction. ${ }^{109}$

In 1979 the FCC refused, lowever, to order cable operators to stop importing network programs from Canadian stations before release of the programs in the United States without proof of harm to the complaining stations. ${ }^{10}$ Border stations complained that these "prereleased" signals fragmented their audiences. ${ }^{111}$ They claimed that after the court's remand order in KIRO, Inc. v. FCC ${ }^{112}$ the FCC could not, consistent with the nonduplication rule procedures, require proof of harm froin the complaining stations. ${ }^{113}$ Nonetheless, the FCC placed the burden of proving liarm on these parties. ${ }^{114}$

106. Cf. text accompanying notes $25-26,36$ supra (amount broadcasters can pay for programs determined by audience drawing power of a program).

107. 47 C.F.R. $\S \S 76.92-.99$ (1979).

108. Id. $\$ 76.92(a)$. The general rule is riddled with exceptions. See, e.g., id. §76.95(a) (if station requesting deletion runs program in black-and-white, cable system need not delete if it runs program in color).

109. Applicability of Section 325(b) of the Communications Act to Non-Interconnected Distribution of Television Programming to Certain Foreign Stations, 75 F.C.C. 304, 308 (1979) (Report and Order), $a f f^{\prime} d$ sub nom. KIRO, Inc. v. FCC, 631 F.2d 900 (D.C. Cir. 1980) [hereinafter cited as Foreign Stations].

110. Id. at 306.

111. Id. at 310-22.

112. 545 F.2d 204 (D.C. Cir. 1976). In KIRO, the FCC had denied KIRO-TV, a network affiliate in Seattle, protection against cable importation of network prograuns aired by Canadian stations before the prograuns' release in the United States, absent a showing of specific harm. The court remanded the decision, finding it inconsistent with the FCC's rule allowing KIRO-TV to halt a cable systen fron airing a program sinultaneously, especially since prereleased programs pose a greater threat to a station's audience size than do simultaneously run programs. $545 \mathrm{~F} .2 \mathrm{~d}$ at 208-09. The 1979 proceeding followed that reinand.

113. Foreign Stations, supra note 109, at 306.

114. Id. The District of Colunbia Circuit upheld the FCC's decision, KIRO, Inc. v. FCC, 631 F.2d 900 (D.C. Cir. 1980), but only because it found that even if KIRO had been given a presuniption of harm consistent with the nonduplication rules, the cable systems would properly have been granted a waiver because they showed that importation in this particular case will not harm KIRO-TV. $631 \mathrm{~F} .2 \mathrm{~d}$ at 907 . Because the complaining stations conld not show specific harm, the FCC concluded that regulation of cable carriage of Canadian stations' prereleased signals wonld not be reasonably ancillary to broadcast regulation, $i d$, as required by United States v. Southwestern Cable Co., 392 U.S. 157 (1968). The FCC therefore concluded that it lacked the jurisdiction to protect the American border stations.

Between the 1976 remand and the 1979 proceeding, the FCC maintained consistency with 
The resolution of the complaint of the border stations deinonstrates a pronounced shift in FCC policy. The 1972 network programming nonduphication regulations were based on the assumption that the cable system should bear the burden of proving that its broadcasts did not harm the local stations. In the recent border station dispute, the FCC put the burden of proof on the local stations to prove that they were harmed by the cable system. The FCC thus seems to be moving toward deregulation even in the one major area in which no formal deregulation has yet occurred. This trend, combined with last summer's withdrawal of the distant signal importation and syndicated program exclusivity regulations, indicates that continued deregulation of cable is likely.

Throughout the history of FCC regulation of cable, the Commission has, of necessity, primarily followed one approach: prohibiting various categories of cable programming. The FCC has used these prophylactic restraints to pursue two goals. All of the regulations discussed above operated to protect local broadcasters against competition with cable-competition which the broadcasters continue to regard as unfair, because cable operators pay little for their programming. In addition, some of the regulations protected the property rights of producers in their programs. Such regulations include the 1968 retransmission consent provisions, as well as the 1972 syndicated exclusivity and network programming nonduphication regulations. The former attempted to give the producers some control over their shows; the latter attempted to prevent destruction of the programs' value in one market due to importation from another. Unfortunately, the tools available to the FCC inefficiently serve the pursuit of these goals. Of necessity, any use of prohibitions against particular types of programming restricts the diversity of viewing available to the consumer. Indeed, the 1968 regulations took this problem to its extreine: Development of cable virtually halted. Furthermore, the regulations tended to protect broadcasters from virtually all competition with cable, whether "unfair" or

KIRO by initially positing an easily rebuttable presumption of harm. See, e.g., Vanhu, Inc., 65 F.C.C.2d 986 (1977). The cable system would then have to show an absence of grounds for prohibiting cable carriage of prereleased programs to the particular market. See, e.g., United Community Antenna Sys., Inc., 67 F.C.C.2d 1376 (1978).

Border stations can still obtain relief, but only on "showing clearly, with reference to specific facts, that the station will be unable to continue to operate in the public interest absent rehef." Foreign Stations, supra note 109, at 339. Currently, this ruling leads to an odd result: Under nonduplication rules, cable operators have the burden of showing no harm where a simultaneous broadcast of network programming is involved, but the local stations have the burden of proving harm to prevent an advance cable showing, a inore serious threat to their economic viability. Id. at 344 (Washburn, Comm'r, dissenting). See also 631 F.2d at 907 (Justice Bazelon's chastisement of the FCC for maintaining conflicting standards). 
not, while they inadequately protected the prograin producers' property rights in their prograins.

\section{B. Copyright Law}

Recognition of retransmission by cable as copyright infringeunent would be a inore direct and less burdensoine ${ }^{115}$ inethod of protecting property rights than is FCC regulation. Producers could then preclude cable importation into a target inarket or extract a fee for it, preventing unfair audience fraginentation and inarket spoilage. Present law does not provide this protection. Instead, it imposes a systein that provides partial payinent when the system is working optimally, no payinent when it is not.

Section $111^{116}$ of the copyright law ${ }^{117}$ exempts eligible ${ }^{118}$ cable operators froun full copyright liability for retransmission of non-network programs. ${ }^{119}$ They inust, however, pay a graduated percentage fee to the Register of Copyrights. ${ }^{120}$ These fees are to be distributed to program producers. ${ }^{121}$

Although there have been no cases challenging this distribution system, many commentators have criticized it. ${ }^{122}$ First, coinpulsory licensing fees bear no relationship to the prices that inarketplace negotiation would produce. ${ }^{123}$ Since the fees are generally below prices broadcasters pay for equivalent services, ${ }^{124}$ the prograin producers re-

115. See Economic Relationship, supra notc 20, at 714 .

116. 17 U.S.C. \& 111 (1976).

117. Id. $\$ \$ 101-810$.

118. Cable operators are generally eligible for the exemption if they file subscribership, revenue, and importation information, and carry only those signals the FCC's regulations allow. Id. $\S \S 111(\mathrm{c}),(\mathrm{d})$.

119. Section 111 applies only to the carriage of non-network programming. Id. §111(f). Congress believed that because copyright owners' contracts assnme fnll network area coverage, distant signal importation does not hurt them. REPORT OF THE HOuSE COMM. ON THE JUDIClary, Copyright Law Revision, H.R. Rep. No. 94-1476, 94th Cong., 2d Sess. 90, reprinted in [1976] U.S. CODE CONG. \& AD. News 5659.

120. 17 U.S.C. $\$ 111(c)(1)$ (1976). Congress implemented this remedy, rather than full copyright liability, assertedly because of the fear that the transaction costs of each cable operator's negotiating with individual program producers over their program rights would be so high that it would be impossible for the cable operator to gain those rights. See Cable Television Syndicated Program Exclusivity Rules, 45 Fed. Reg. 60,186, 60,223 n.256 (1980). There is no reason to beheve, however, that cable networks similar to broadcast networks could not form to bargain collectively over those rights. See Note, supra note 66, at 1701-03.

121. 17 U.S.C. $\$ \S 111$ (c)-111(d) (1976).

122. See, e.g., Besen, Manning \& Mitchell, supra note 5; Botein, The New Copyright Act and Cable Television-A Signal of Change, 24 BuLL. CR. Soc. 1 (1976); Meyer, The Feat of Houdini or How the New Act Disentangles the CATV-Copyright Knot, 22 N.Y.L.S. L. REv. 545 (1977).

123. Besen, Manning \& Mitchell, supra note 5, at 88.

124. Id. at 88-91. Besen, Manning, and Mitchell concluded this from the following observations: In 1974, advertisers paid $\$ 2.80$ per month for the average TV home, and independent stations paid about $25 \%$ of their revenues, i.e., $\$ .70$ per customer, to program suppliers. Park, 
ceive inadequate revenues.

Section 111 also fails to provide the producer any compensation for revenue losses caused by the inability of local stations to pay the same fees for a program that they might have paid had their audiences not been fraginented by early importation of the program. ${ }^{125}$ If the producer were fully compensated for this loss by royalties paid by the importing cable system, section 111's compulsory licensing scheme would do him no harm. Under section 111, however, the royalties paid are insufficient to cover the loss of revenue from local stations, yet the producer cannot prevent the damaging importation. Thus, section 111 prevents the producer from scheduling release of his prograin so as to maximize return.

Furthermore, compulsory licensing requires a costly fee distribution mechaminin, whicl w was worked out only last September, ${ }^{126}$ nearly two years after section 111's effective date. In addition, the costs of resolving disputes are deducted from the fund before distribution. ${ }^{127}$ Under this system, producers receive inadequate revenue froin cable systems, probably receive lowered revenue from local broadcast stations, and lose revenue by having to pay the expenses of the distribution system. Because producers receive inadequate revenues, they will not allocate as many resources to prograin production as they would if they knew they would receive adequate revenues.

The second problein with the compulsory hicensing systein is that the rate schedules are inflexible and ultimately unpredictable. Scction 111 allows reasonable changes in the rate schedules, but only if the FCC revises its cable regulations or if prices rise generally. ${ }^{128}$ The law does not specify low the rates should change in response to an FCC

Johnson, and Fishman's study, R. PARK, L. Johnson \& B. Fishman, Projectino the Growth OF TELEVISION BROADCASTING: IMPLICATIONS FOR SPECTRUM USE (RAND 1976), suggests that if two additional stations are imported, cable subscribers will view the local independents half as often as they did before importation. Local independents will then pay only $\$ .35$ per custoiner. Thus, in order to coinpensate for the revenue loss, program suppliers must find coinpensating revenues of about $\$ .35$ per cable customer. Compulsory licensing will generate offsetting revenues of $\$ .07$ per subscriber on large cable systems. Additional revcnues will come from regional and national advertisers advertising on the imported stations' programs. However, these revenues are likely to be less than the local stations' loss, since advertisers who value the audience highly (local advertisers) are being replaced by those who value it less (the national and regional advertisers). See also Botein, supra note 122, at 15; Meyer, supra note 122, at 560; Freeing of Cable Television by F.C.C. Facing Legal Challenges, N.Y. Times, July 24, 1980, at C19, col. 1.

125. Botein, supra note 122, at 12.

126. See Van Deerhin, Introduction to Student Symposium on Communications Regulation, 69 Calif. L. Rev. 446 (1981).

127. 37 C.F.R. $\$ 302.10$ (1979) (promulgated under 17 U.S.C. $\$ 807$ (1976)).

128. 17 U.S.C. $\$ 801(\mathrm{~b})(2)$ (1976). Rates may also be revised if cable systeuns on the average raise their subscription fees at a slower rate than general inflation. See id. $\S 801(\mathrm{~b})(2)(\mathrm{A})$. Of course, there is always room for controversy over which price index to use and how often the rates should be revised. See CRT Reviews Inflation's Effect on Cable Payments, Broadcastino, Oct. 
change in the cable rules. ${ }^{129}$ Consequently, the cable copyright controversy cannot be considered settled under this statutory scheme, since cable, broadcasting, and production interest groups would undoubtedly challenge any inodification of the rates stimulated by an FCC rule change. ${ }^{130}$ Yet, without predictable rules and prices, producers cannot efficiently allocate production resources.

This atteinpt to protect producers' property rights was ill-conceived and ineffective. This system of partial paynent to the copyright holder is an administrative nightınare. Congress must repeal this system and enact full copyright hability for cable retransmission in order adequately to protect program producers.

\section{Deregulation}

The FCC has recently eliminated the syndicated exclusivity and distant signal carriage regulations. ${ }^{131}$ The FCC stated that these regulations had been inere substitutes for copyright liability, ${ }^{132}$ intended to have effect only until Congress revised the copyright law. ${ }^{133}$ Since Congress has now revised the copyright law to deal with cable, ${ }^{134}$ these interim ineasures were repealed.

The FCC's elimination of the distant signal carriage regulations began as an inquiry into the relationship between cable television and broadcasting. ${ }^{135}$ The FCC determined that it was time to test the premise underlying the cable regulations, i.e., that distant signal importation harmed broadcasters. Even if the theory of cable importation harm to broadcasters were supportable, the FCC continued, cable might produce counterbalancing benefits for the viewing public justifying a different administrative course. ${ }^{136}$

The FCC now predicts that elimination of the distant signal regu-

13,1980 , at 40 . Moreover, the system does not deal with sudden shifts in the popularity of individual programs, which may lead to more disputes over distribution of the fees.

129. Besen, Manning \& Mitchell, supra note 5, at 91. The only guidance Congress provided was that the Copyright Royalty Tribunal should "consider . . . the econouric impact upon copyright owners and users." 17 U.S.C. \& 801(b)(2)(B) (1976).

130. See Besen, Manning \& Mitchell, supra note 5, at 91-92.

131. See note 76 supra.

132. Syndicated Report, supra note 6, at 962.

133. The cable copyright controversy had been debated for 11 years prior to the 1976 revision. Brief, supra note 59 , at 6.

134. See Copyright Revision Act of 1976, Pub. L. No. 94-553, 90 Stat. 2541 (codified at 17 U.S.C. $\$ \S 101-810(1976)$ ).

135. Proposed Rulemaking, supra note 62, at 1023. The FCC defined three criteria against which it would judge regulatory policy: consumer surplus (the difference between value received and price paid for all consumers), distributional equity, and externalities (social benefits, such as information and its function in a democratic society). Economic Relationship, supra note 20, at 636-39.

136. Economic Relationship, supra note 20, at 635-36. 
lations will have hittle impact on viewers' options between free television programming and cable programming. ${ }^{137}$ The FCC also predicts, however, that network affiliates and independents will suffer some audience loss. ${ }^{138}$ The loss, the FCC contends, will be offset by the high rate of return enjoyed by these broadcasters ${ }^{139}$ and by demand increases due to projected population growth and economic expansion. ${ }^{140}$

The FCC's conclusions can be challenged by noting, for example, that once the broadcasters' hcense acquisition costs are accounted for, rates of return appear more normal. ${ }^{141}$ The agency's approach is inore fundamentally questionable, however, because the FCC assigned to producers and broadcasters the burden of proof ${ }^{142}$ of showing cable's harm. ${ }^{143}$ Due to the economics of the broadcast industry and the failure of the new copyright law to protect producers fully, deregulation poses a serious threat to the property rights of broadcasters and producers. Such considerations indicate that the FCC should assuine the burden of proving that deregulation will not unduly harm broadcasters and producers, contrary to the FCC's current position.

Broadcasters' revenues come from advertisers, who pay for attachment of their messages to attractive programs. ${ }^{144}$ A prograin's appeal, measured by expected viewership, governs how nnuch an advertiser is willing to pay. The program producer bases the fee he charges the broadcaster on this expected appeal.

The program producer's compensation froin cable operators, however, does not depend upon the program's appeal. ${ }^{145}$ Rather, it depends solely upon the size of the operators' revenues. ${ }^{146}$ As argued

137. Proposed Rulemaking, supra note 62, at 1025-26.

138. Economic Relationship, supra note 20, at 661 .

139. Id., (citing R. Noll, M. PeCK \& J. MCGowaN, Economic Aspects of Television REgulation 16-18 (1973)). But see note 141 infra.

140. Economic Relationship, supra note 20, at 661.

141. See Deregulation of Cable Television, supra note 15 , at 34 n.23; R. Noll, M. PECK \& J. MCGowaN, supra note 139, at 16 n.50. License costs would rise during economic expansion, thus keeping rates of return in line with other industries operating under similar risks and legal protections.

142. The FCC disavowed interest in comments arguing who should bear the burden of proof. Economic Inquiry, supra note 21. Moreover, in inquiring whether therc is any present justification for the regulations, the FCC arguably placed an especially onerous burden of proof on the broadcasters and program producers. The relevant question seemed to be whether audience diversion would be such that the viewer would lose the station's programming, not whether the quality of the programming might suffer. See, e.g., Cable Television Syndicated Program Exclusivity Rules, 45 Fed. Reg. 60,186, 60,217 (1980).

143. Cf. text accompanymg notes $110-14$ supra (similar burden placed on broadcasters in the Canadian importatiou proceeding).

144. See text following note 12 supra; note 36 supra.

145. See text accompanying note 123 supra.

146. See 17 U.S.C. $\$ 111$ (d)(2)(B)-(D) (1976). For example, a system with between $\$ 80,000$ and $\$ 160,000$ in revenues importing one "distant signal equivalent" pays $\$ 400$ plus $1 \%$ of all gross 
earlier, this recompense is inadequate. ${ }^{147}$

To the extent that programming will remain the same after the distant signal regulations' demise, ${ }^{148}$ cable operators are likely to carry signals they previously could not, and viewers are likely to view a greater proportion of programming over cable. As the proportion of programming viewed over cable increases, program producers' recompense slould less accurately inatch their product's actual worth. ${ }^{149}$ In other words, inarket distortions caused by the inadequacy of compulsory licensing fees will be magnified.

Distorted and decreased producer incentives diminish the program quality and quantity viewers receive. ${ }^{150}$ Moreover, imcreasing the proportion of programming paid for through an undercompensating and irrational scheme further infringes on the producers' property rights in their programming by limiting their ability to set their own prices. ${ }^{151}$ The FCC recognizes that it has a duty to protect program producers' property interests and broadcasters' interest im order to protect viewers. Thus, the burden should have been on the FCC to prove that there would be no harin to these groups from eliminating the distant signal restrictions, rather than on the broadcasters or producers to prove that harn would occur.

More significant, however, is the overarching fact that prophylactic restrictions on expansion of cable retransmission, such as the distant signal importation limitations, realistically can only attempt to provide the incentives that will lead to efficient allocation of production resources. No administrative agency can hope to analyze or keep up with the myriad of rapidly changing economic forces in the broadcast industry. Thus, government regulation of the price or quantity of programming will always tend to suffer from inflexibility and inefficiency.

\section{III}

\section{Proposal}

One way of avoiding this problem would be to use property law concepts, rather than prophylactic regulations, to protect producers'

revenues above $\$ 80,000$. See id. $\$ 111$ (d)(2)(D). Generally carriage of an independent station equals one distant signal equivalent and carriage of a network or noncommercial educational station equals one-fourth of one. Id. $\$ 111(\mathrm{f})$.

147. See note 124 supra.

148. See Economic Relationship, supra note 20 , at $660-61$.

149. See Besen, Manning \& Mitchell, supra note 5, at 92.

150. See Syndicated Report, supra note 6, at 977. The FCC recognized that the elimination of the syndicated exclusivity rule could slow the expansion of the supply of programming, Cable Television Syndicated Program Exclusivity Rules, 45 Fed. Reg. at 60,226 (1980), which, froin a policynaking perspective, is arguably the same as reducing the supply.

151. See Proposed Ruleinaking, supra note 62, at 1029. 
rights in their programs. Then cable could be allowed to expand uninhibited by any such categorical prohibitions. Nobody would need to make a showing of net social benefit before expanding or changing, as has been necessary under the various FCC-imposed rules. Since competition would then be fair, the market could be depended upon efficiently to serve as the ultimate arbiter, just as it does with any other innovative technology. ${ }^{152}$

Retransmission consent rules and full copyright hability rules ${ }^{153}$ are two property right frameworks that theoretically would accoinplish the goal of assuring program producers compensation equal to the full value of their programs, thus assuring socially optimal program production. ${ }^{154}$ They should also function equally well-they are inerely different approaches to creating property rights in television signals. Under a retransmission consent rule, the broadcaster has the property rights, while a full copyright liability system vests the rights in the program producers. A simple Coasian ${ }^{155}$ analysis shows that the two systems of allocating property rights do indeed work alike, but

152. See Deregulation of Cable Television, supra note 15 , at 46 . The authors, however, argue that cable television should be treated differently, citing three probleuns stemming from free competition: regulated firms' expectation interests in protection; harmful effects to nonpecuniary regulatory goals, such as localisin; and harmful redistributional effects.

An expectation of protection appears valid only in the absence of fair competition. Within a free and fair inarket framework, these protection expectations should disappear.

Neither of the remaining objections are arguments for requiring a cost-benefit analysis before allowing new technology onto the market, but are merely indications that regulation may be appropriate.

Here, however, regulation has been found unnecessary. For exainple, the FCC has abandoned localist cable regulation, relying instead on the market. See, e.g., Leapfrog Amendments, supra note 86, at 636-39 (cable operators will carry local programming because of subscriber demand and high microwave costs: thus no need for anti-leapfrogging rules); Amendment of Part 76, Subpart G of the Commission's Rules and Regulations Relative to Program Origination by Cable Television Systems, 49 F.C.C.2d 1090 (1974) (Report and Order) (applying same approach to repeal cablecasting rules).

Finally, at the very most, redistributional goals may favor imposing new regulations despite social mefficiency. Rather than retaining an inefficient system, however, it seems inore rational to simply redistribute income explicitly through cash grants to whatever extent society feels appropriate.

153. For an explanation of these terms, see notes 7-8 supra.

154. See Besen, Manning \& Mitchell, supra note 5, at 87 n.56. The following discussion generally follows and expands on the material in the cited footnote, adding, however, a necessary step in the analysis. See also Syndicated Report, supra note 6, at 977 n.60.

155. The Coase theorem indicates that where transaction costs are zero, the allocation of productive resources will be unaffected by the initial distribution of property rights. Coase, The Problem of Social Cost, 3 J.L. \& ECON. 1 (1963). For example, imagine a corn farmer and a cattle rancher on adjacent parcels of land. Every month, the rancher's cattle destroy $\$ 30$ of corn. If a fence costs $\$ 25$ and the rancher is liable for the damage his cattle do, he will build it. If the rancher is not liable, the farmer will build the fence. In either case, then, the fence will be built, and five dollars of resources will be saved. The initial placement of entitlements affects only the distribution of wealth between the two parties. 
consideration of transaction costs demonstrates that the latter is more efficient. The following example demonstrates this conclusion.

\section{A. Simple World Analysis}

Suppose that there are two television stations $(A$ and $B)$ in separate inarkets, one program producer $(P)$, and one cable operator $(C)$ with a microwave link between the markets. ${ }^{156}$ In $A$ 's market the program attracts audiences and advertising revenues such that $A$ is willing to pay $P$ thirty dollars. If the program and its advertising were retransmitted to $B$ 's market, $A$ would be willing to pay $P$ thirty-five dollars, because his advertisers would reach an additional market, and would pay $A$ more for commercial time. With $A$ 's signals imported into $B$ 's market, however, $B$ would lose audience and revenues, and could pay $P$ only fifteen dollars, instead of the twenty-five dollars he would be willing to pay without the imported signals' competition. Finally, suppose $C$ receives subscription revenues, net of retransmission expenses, justifying a payment of fifteen dollars for retransmission rights or copyright heensing.

Under a retransmission consent regime, $A$ has the right either to grant to, or withhold from, $C$ permission to retransmit $A$ 's signal. $C$ will pay $A$ fifteen dollars for permission. Advertising revenues would rise to thirty-five dollars. Thus, if $A$ grants permission to $C$, he will receive fifty dollars. On the other hand, $B$ will pay $A$ up to ten dollars to withhold permission to retransmit, since with retransmission $B$ suffers an audience loss worth ten dollars. If $A$ withholds permission, he would receive thirty dollars from his advertisers, for a total of forty dollars. $A$ would clearly opt for retransmission.

Under a full copyright hability regime, the program producer retams the right to grant or refuse cable operators permission to retransmit broadcast signals. In the above situation, $P$ would face a similar choice. $P$ could refuse retransmission permission and collect thirty dollars from $A$ and twenty-five dollars from $B$, or grant retransmission permission and collect thirty-five dollars from $A$, fifteen dollars from $B$, and fifteen dollars from $C$. $P$ would thus favor retransmission under these circumstances. Both systems yield the same result: retransmission of the program.

Suppose, however, that importation fragmented $B$ 's audience more severely, so that $B$ could afford to pay $P$ only four dollars, rather than the twenty-five dollars he would pay if he had no competition from $A$ 's imported signal. Under a retransmission consent system, $B$

156. And assume further that program prices are competitive, so that price equals marginal cost. 
would be willing to pay $A$ up to twenty-one dollars to deny $C$ permission to retransmit $A$ 's signal. Without retransmission, $A$ would receive thirty dollars from advertisers for his own showing of the program, so the total value to $A$ would be fifty-one dollars. If $A$ were to grant retransmission consent, he would receive the fifteen dollars that $C$ is willing to pay. The total value to $A$ in that case would be fifteen dollars added to the thirty-five dollars which $A$ will receive for showing the program with retransmission, or fifty dollars. Therefore, $A$ will deny $C$ consent to retransmit $A$ 's signal.

Under a full copyright liability system where the producer has the power to grant or deny consent to retransmit, similar results occur. With retransmission, $P$ would receive fifteen dollars from $C$, thirty-five dollars from $A$, and four dollars from $B$, for a total of fifty-four dollars. Without retransmission, $P$ would receive thirty dollars from $A$ and twenty-five dollars from $B$, for a total of fifty-five dollars. $P$ will not grant retransmission rights. In the simple analysis, then, whether a program is retransmitted by cable does not depend on whether property rights are allocated by the retransmission consent rule or by the copyright hability rule.

\section{B. Complex World}

Suppose, however, as im the real world, there are not merely one $A$ and $C$, but rather many $A$ 's (i.e., stations which can be imported into $B$ 's inarket) and several $C$ 's im $B$ 's inarket. ${ }^{157}$ In order to avoid fragmentation of the audience for a particular program under the retransmission consent rule, $B$ will have to seek out every $A$ carrying the program and pay each of them not to grant the $C$ 's retransmission consent. Since this effort will be expensive, $B$ may not be willing to finance it. Thus, the $A$ 's will receive no "bribes" from $B$ for denial of permission to retransmit. In this situation the $A$ 's can treat retransmission consent as a public good-it does not cost them anything in terms of foregone bribes to grant it. Therefore, any $A$ will grant a $C$ retransmission consent.

However, a profit-maximizing copyright holder $(P)$ might deny all $C$ 's permission to retransmit under a copyright liability system. $B$ would not have to seek out each $A$ carrying the program, because $B$ 's single payment to $P$ for exclusive rights would also protect $B$ from audience fragmentation. Moreover, permission to retransmit a program granted to a $C$ would preclude other $C$ 's from retransmitting that program. Thus, a producer is more likely to receive the full value of his

157. Assuming $B$ 's market is a multi-city one, municipal exclusive franchising practices unay not reduce the number of $C$ 's to a sufficiently small number so as to enable $B$ to pay the $C$ 's not to import $A$ 's signals. 
program under a copyright liability system than under a retransmission consent system.

A retransmission consent regime would lead to undercompensation of producers in another way. The program producers would be able to extract a soinewhat higher payment from the $A$ 's because the $A$ 's have the right to give retransimission consent and will charge cable systems for that consent. But the producer will not thereby be able to obtam the full value of the retransmission of his program. Since giving retransmission consent costs the $A$ 's nothing, they will compete to grant consent to the cable systems. Accordingly, the $A$ 's will lower their prices to a point where each $A$ will charge a cable system at most an amount equal to the extra microwave costs to the cable operator of importing from the next closest $A{ }^{158}$ The cable operator will end up paying to the lucky $A$ a mere locational rent, which will be less than the value the cable system's subscribers place on the program. Thus, the additional payments that the producer can extract from the lucky $A$ will reflect only the locational rent, and not the program's true value.

Hence, while in theory the allocation of programming resources would be the same whether the origmal property rights are placed with program producers or their initial licensees (the $A$ 's), in a more complex world, due to transaction costs, the origmal placement will have an allocational effect. In such circumstances, the rights should be assigned in the most economically efficient way. ${ }^{159}$ Under retransmission consent, cable system operators would end up paying the imported station fees that do not reflect how inuch the operators' subscribers value the programs imported. Rather, the fees would be based merely on the imported station's location and that location's effect on iniportation costs. Full copyright liability would make it more likely that program producers will capture their programs' full incremental value to viewers, smce each program price is individually bargained over. ${ }^{160}$ To this extent, the program producers will supply a more optinial quantity and quality of programming.

IV

CONCLUSION

Cable television was technologically new in the early 1950's, but remains jurisprudentially new today. The property rights framework for cable has yet to be settled. Division of regulatory power may be

158. For example, assume it costs a cable system $\$ 20,000$ to import from $A_{1}$ and $\$ 21,000$ to import from $A_{2} \cdot A_{2}$ will be willing to bring its price to zero. If $A_{1}$ charges $\$ 1,000$, the cable systein will be indifferent as between the two. If $A_{1}$ charges $\$ 999$, it will be the lowest bidder.

159. R. POSNER, ECONOMIC ANALYSIS OF LAw (2d ed. 1977).

160. See Besen, Manning \& Mitchell, supra note 5, at 86. 
one cause for cable's continued jurisprudential disruptiveness. The FCC has struggled for years, imposing various prophylactic restraints on cable while remaining powerless to impose full copyright liability. More recently, it has decided to deregulate, finding that within the current regime the regulations are more costly than beneficial. The deregulation itself has already been challenged. ${ }^{161}$ If the deregulation is upheld, broadcasting, cable, and production interests will undoubtedly challenge the Copyright Royalty Tribunal's rate schedule reaction. Under this new regime, there is no long range certamty of return for those mvestimg in program production, which prevents the optimal allocation of resources to such production.

Congress, therefore, should intervene and impose full copyright liability. Under such a system, cable operators or cable operator networks would bargain with program producers for the right to import their programs from any given market to any other market. Program producers, knowing the viewing habits in every market, could set their prices to extract froin cable operators the full value that the operators' subscribers place on their programs. Thus, cable operators would finally be on the same footing as broadcasters in the program purchasing market. Cable could then be set free, to sink or swim in fair competition. With due haste from Congress, perhaps this can be accomphished before the next technological revolution.

Gillis L. Heller*

161. See note 76 supra.

* B.A. 1978, University of Washington; third-year student, Boalt Hall School of Law. 